\title{
Development and Evaluation of Psychometric Properties of an Inventory of Teachers' Perceptions on Socio-Emotional Needs
}

\author{
Desenvolvimento e Avaliação das Características Psicométricas \\ do Inventário de Avaliação das Percepções dos Professores acerca \\ das Necessidades ao Nível da Promoção de Competências Sociais e Emocionais
}

\author{
Paulo A. S. Moreira*, ${ }^{*}, c$, Ana Pinheiro ${ }^{b}$, Paulo Gomes ${ }^{c}$, Maria João Cotter ${ }^{c} \&$ Randy Ferreira ${ }^{c}$ \\ ${ }^{a}$ Universidade Lusiada do Porto, Porto, Portugal \& ${ }^{b}$ Universidade do Minho, Braga, Portugal \\ ${ }^{c}$ Centro de Investigação em Psicologia para o Desenvolvimento, Porto, Portugal
}

\begin{abstract}
The objective of this study was to evaluate the psychometric properties of an assessment instrument on teachers' perceptions regarding the development of socio-emotional skills. Results revealed a consistent four-factor structure (School/teachers' needs for socio-emotional skills promotion; Needs regarding teaching-learning process; Difficulties in dealing with students' socio-emotional deficits, Socio-emotional needs related to teacher's initial training) with internal consistency values above .79. Confirmatory analyses revealed a good fit of the model to the data. Teachers reported having more needs at the school/ teachers conditions for the promotion of social and emotional needs, and less needs at the level of their Teachers' initial training. The instrument also showed to be sensitive in capturing teachers' perception of schooling social and emotional needs in terms of teachers' gender, pedagogic group and school level. Keywords: Instrument development, teachers perceptions, social and emotional skills, social and emotional learning.
\end{abstract}

\begin{abstract}
Resumo
O objectivo deste estudo foi avaliar as características psicométricas de um instrumento de avaliação das percepções dos professores acerca das suas necessidades na promoção das competências sociais e emocionais. Os resultados revelaram uma estrutura de quatro factores (Necessidades ao nível da escola/ professor, necessidades ao nível do processo de ensino-aprendizagem, Dificuldades em lidar com défices sócio-emocionais dos alunos e Necessidades ao nível da formação inicial), com valores de consistência interna acima de 0,79 . As análises confirmatórias revelaram bom ajustamento do modelo aos dados. Os professores revelaram sentir maiores dificuldades ao nível das condições da escola/ professores e menores ao nível da formação inicial. O instrumento revelou-se também sensível às diferenças de percepções em termos do género, grupo pedagógico, e nível de ensino.

Palavras-chave: Desenvolvimento de instrumento, percepção dos professores, competências sociais e emocionais, aprendizagem sócio-emocional.
\end{abstract}

Social and emotional skills have a significant impact on academic performance (Durlak, Weissberg, Dymnicki, Taylor, \& Schellinger, 2011), on school attendance and school dropout (Archambault, Janosz, Morizot, \& Pagani, 2009), academic adjustment (Howse, Calkins, Anastopoulos, Keane, \& Shelton, 2003), academic competence (Izard et al., 2001; Welsh, Parke, Widamen, \& O'Neil, 2001), the academic motivation and success (Pritchard \& Wilson, 2003), including in at risk and disadvantaged

\footnotetext{
*Endereço para correspondência: Universidade Lusíada do Porto, Centro de Investigação em Psicologia para o Desenvolvimento, Rua Dr. Lopo de Carvalho, Porto, Portugal, 4369-006. E-mail: paulomoreira@por.ulusiada.pt
}

students (Becker \& Luthar, 2002), and on prevention of achievement loss associated with middle school transition (Rosenblatt \& Elias, 2008). Social and emotional skills have a strong influence on students' engagement with school (Reschly, Huebner, Appleton, \& Antaramian, 2008), and on school environment (Battistich, Solomon, Kim, Watson, \& Schaps, 1995). A recent meta-analysis evaluated the impact of universal school-based interventions for the promotion of social and emotional skills in students, from kindergarten through high school. This meta-analysis give empirical evidence for the positive impact of the promotion of social and emotional skills on social and emotional skills, attitudes, behaviors and on academic performance, reflecting significant gains in 
academic achievement (Durlak et al., 2011). Several indicators of socio-emotional functioning (such as selfcontrol, self-regulation and self-discipline) are associated to academic performance (Duckworth \& Seligman, 2005; Kurdek \& Sinclair, 2000).

Also, social and emotional skills have a significant impact on engagement in appropriate relationships in middle childhood (Denham et al., 2003), reduce aggressive reactivity (Pavarini, Loureiro, \& Souza, 2011), predict peer acceptance (Mostow, Izard, Fine, \& Trentacosta, 2002), social and behaviour outcomes (Fine, Izard, Mostow, Trentacosta, \& Ackerman, 2003), and responsible behavior (Bear, Manning, \& Izard, 2003). The efficacy of the school-based programmes that promote social and emotional competences is well established (Greenberg et al., 2003), at a cross-cultural level (Kimber, Sandell, \& Bremberg, 2008; Moreira, Crusellas, Sá, Petracchi, \& Matias, 2010). There is a need for educational reform and policies to include systematic promotion of social-emotional skills in school children (Guerra, Graham, \& Tolan, 2011; Merrel, 2002), and for school curricula to dedicate more attention to social and emotional learning (Buckley, Storino, \& Saarni, 2003).

Because teachers are crucial agents on the school-based social and emotional skills promotion programmes and strategies, and determinant to their efficacy on school settings (Martin, 2007), it is desirable that they have a greater involvement in the promotion of social and emotional competencies in schools (Moreira et al., 2010), especially in at-risk students (Preto \& Moreira, 2012). Understanding teachers' difficulties on a social and emotional competences promotion level is a central aspect for an effective preparation of teachers on this field, allowing changes to be implemented in the initial teachers' training and to outline professional development activities that will fulfill these needs.

\section{Teachers'Beliefs and Perceptions}

Perceptions are complex processes which include motivations, cognitions, emotions and behaviors (Weiner, 1995), and is the filter from where an individual understands reality (Johnson, 1987). An individual's perception shapes his own attitudes and behaviours, in function of the representations he or she makes of those same stimuli (Johnson, 1987). Teachers' perceptions and beliefs guide their behaviors and practices in the classroom (Lam \& Kember, 2006), as they allow understanding, predicting and influencing their behaviors in teaching contexts (Poulou, 2006) and their classroom practices (Pavri \& Hegwer-DiVita, 2006). Also, they are crucial instruments of schooling-learning practices improvement, of schools processes of improvement and of school's efficacy (Pedder \& MacBeath, 2008), once they allow for the identification of difficulties and the development of strategies which seek to answer the necessities and difficulties felt by the teachers. Teachers perceptions and evaluations and students outcomes are bidirectional processes and transactional models have shown that teachers perceptions of their students play a significant role in several students dimensions, including in personality development (Heaven, Leeson, \& Ciarrochi, 2009).

Cruickshank (1980) proposed a classic typology in which he grouped teacher's problems or difficulties into five areas: (a) affiliation: the need to establish and maintain good relationships with others in the school, both students and staff; (b) control: the need to have students behave appropriately; (c) parent relations and home conditions: the need to relate and work well with adults outside the school who are important in the lives of students and the need to understand home conditions; (d) student success: the need to have academically and socially successful students; and (e) time: the need to be efficient managers of their personal and professional lives. A more recent systematization suggests that teachers need help with (a) classroom management, (b) understanding of the school's procedures, (c) learning content and child development of a specific grade, (d) communicating effectively with parents, (e) and learning to work in isolating conditions (Stanulis, Fallona, \& Pearson, 2002). Qualities of effective teachers include teachers' taking responsibility also for students' behaviors and their determinant factors (Darling-Hammond, 2000; Darling-Hammond, Holtzman, Gatlin, \& Heilig, 2005; Stronge, 2007). This is an idea shared by the several models on teaching-learning process, including classic models such as the Carroll's of school leaning (Carroll, 1963, 1989), the Slavin's model of effective instruction (Slavin, 1995), the Cruiscksank's model of the effective teacher (Cruickshank, 1985), and recent models, such as the Huitt's transactional of teaching/learning process (Huitt, 2003), the Darling-Hammond model (2000) and the Cremers and Kyriakides's school efficacy dynamic model (Cremers \& Kyriakides, 2006).

\section{Teachers' Perceptions of Schooling \\ Socio-Emotional Needs}

Society demands require additional competences in areas such as emotional conscience, decision making, social interaction and conflicts resolution (Poulou, 2006), which justifies the inclusion of these parameters by schools and teachers, following and even anticipating societies' developments (Maandag, Deinum, Hofman, \& Buitink, 2007).

Thus, it is natural that the promotion of social and emotional competences in children within scholar contexts, which is also known as socio-emotional learning (Coryn, Spybrook, Evergreen, \& Blinkiewicz, 2009), has gradually been included in scholar curricula in the form of curricular infusion (Moreira et al., 2010). The necessity of providing teachers with competences to efficiently promote social and emotional competences in children is a direct consequence of this tendency. However, teachers' initial training is inadequate when preparing them to deal 
Moreira, P. A. S., Pinheiro, A., Gomes, P., Cotter, M. J. \& Ferreira, R. (2013). Development and Evaluation of Psychometric Properties of an Inventory of Teachers' Perceptions on Socio-Emotional Needs.

with current society challenges (including children's socio-emotional functioning; Maandag et al., 2007).

School characteristics and teachers skills have a significant impact also on students' academic achievement (Rivkin, Hanushek, \& Kain, 2005). By one hand, students identify the academic but also the social dimensions of schools as important aspects of positive school social climate (Tetler $\&$ Baltzer, 2011). By another hand, the importance of the teachers role in identifying and reporting deficits and needs in students socioemotional functioning is been increasingly acknowledged (Lundervold, Posserud, Ullebo, Sorensen, \& Gillberg, 2011). Teachers consider that students social skills necessary for success in elementary school classrooms (Lane, Givner, \& Pierson, 2004).

Recent studies have shown that teachers' evaluations and perceptions have a significant role on teachersstudents interactions and on teachers' behaviors for the promotion of students' adaptive biopsychosocial development (e.g. students' personality development; Heaven et al., 2009). This fact is especially relevant due to the fact that teacher/students interaction, and teacher support are also associated to students engagement with school and achievement (Klem \& Connel, 2004). A better understanding of the interaction between teachers' perceptions about their needs and self-efficacy in promoting adaptive students' socioemotional development allows for the development of multidimensional models of teachers efficacy in the promotion of social and emotional skills. It is essential that the necessities felt by teachers in terms of socio-emotional learning are given particular attention, thus identifying their perceptions about/on the needs that allow the development of strategies that are helpful in satisfying teachers' needs in terms of the promotion of social and emotional competences (Buckley et al., 2003). The assessment of educative agents' perceptions in terms of needs in social and emotional dimensions is crucial to the promotion of social and emotional competences (Payton et al., 2000). In fact, one of the main present limitations to a better understanding of teachers' perceptions of social and emotional schooling needs is the inexistence of teachers' perceptions of schooling social and emotional needs assessment instruments. One way of contributing to the development of this field of investigation is the development of teachers' perceptions assessment instruments to systematically understand their difficulties in terms of social and emotional competences.

\section{Objectives of this Study}

The aim of this study was to develop and validate a teachers' perceptions instrument to assess teachers' needs in terms of their competences in promoting social and emotional skills. Besides, this study evaluated the dimension in which teachers felt more needs in promoting socioemotional skills, and the differences on teachers' perceptions about their needs in promoting social and emotional skills accordingly to several teachers' socio-demographic and professional variables.

\section{Method}

Firstly, we made an exploratory and qualitative analysis with teachers about the domains of teachers' activities they felt being relevant for the promotion and social and emotional skills. Exploratory interviews were made to several teachers. Teachers' were asked to identify the areas or domains in which they feel to have more needs in terms of the promotion of social and emotional skills. Then, we made a content analysis, and the answers were grouped by categories. Six dimensions were consensual amongst the teachers. 48 items were formulated and distributed by the 6 dimensions. These items were discussed with experts on teacher education, experts on teachers' professional development and on experts on social and emotional skills promotion (teachers and psychologists who were developing, implementing and evaluated school-based programs for the promotion of social and emotional skills). The selection of the items to be included and their distribution by the four dimensions was made based on the content analysis described above. After the Principal Components Analysis, these dimensions were reduced to 4 dimensions (39 items; based on both statistical and conceptual criteria): Socio-emotional needs related to teacher's initial training, Students' learning socio-emotional needs, School/teachers needs for socioemotional skills promotion, Learning - teaching process socio-emotional needs.

\section{Participants}

Schools were contacted and were invited to participate in the study. Those teachers who gave their informed consent were included in the study. The sample was constituted by 266 teachers that taught in various elementary and secondary schools of the north of Portugal during the school year 2006/2007.In terms of gender $23.3 \%(n=62)$ were male while $76.7 \%(n=204)$ were female. Ages ranged from 23 to 65 years $(M=39.46 ; S D$ $=9.163$ ). These teachers taught various subject matters: $32.8 \%$ humanities and social sciences $(n=78), 29.4 \%$ elementary school $(n=70), 19.3 \%$ exact sciences and maths $(n=46), 7.1 \%$ gymnastics $(n=17), 4.6 \%$ arts and music $(n=11)$ and $6.75 \%$ other subjects (such as technologies, informatics, economy or accounting; $n=16$ ). Relatively to the amount of years of service there were individuals with a minimum of one year of service to a maximum of 37 years $(M=15.32, S D=9.30)$.

\section{Data Analysis Procedures}

Descriptive statistics analysis and principal components analysis were carried out using the Statistical Package for Social Sciences (SPSS) for Windows, version 17.0. Mean differences were tested using the $t$ student test. A series of CFAs were conduced on a sample of primary and secondary school teachers. Two models were tested in the sample: In model 1, was tested if all factors were independent and in model tested all the factors interrela- 
ted. To further assessment of the validity of the measure it was used a Confirmatory Factor Analysis with the software AMOS 16.0 using maximum likehood procedure as technique for parameter estimation. To test mean differences and correlations, parametric tests were used ( $t$ student test and Person Correlation test). The calculation of the normalized values for each scale was made using the following formula:

$$
X_{n e w}=\frac{X-X_{M i n}}{X_{M a x}-X_{M i n}}
$$

\section{Instrument}

The Teachers' perceptions of socio-emotional schooling needs inventory (TEPESSENI) was developed to evaluate teachers' perceptions of their own needs during the teaching-learning process. It measures four dimensions, throughout 39 items, scored via a 5-point Likerttype scale $(1=$ Totally Disagree, $2=$ Disagree, $3=$ No agree, nor disagree, $4=$ Agree and $5=$ Totally agree). The dimension of Socio-emotional needs related to teachers' initial training (12 items), measures teachers' perception about how their initial training has prepared them to deal with students' social, emotional and behavioral dimensions. The dimension of coping with students' socio-emotional deficits ( 7 items), measures the teachers' perceptions about their needs in coping with students' socioemotional deficits. The dimension of School/teachers needs (6 items), measures teachers' perceptions about school and teachers conditions for the promotion of social and emotional skills. The dimension of Learningteaching process socio-emotional needs (14 items), measures teachers' perceptions about their difficulties in integrating social and emotional skills promotion in their daily teaching practices.

\section{Coding instructions}

The scale of "Initial training" is composed by 12 items: items $1,4,7,8,12,16,20,23,28,31,35$ and 38 .

The scale of "Coping with Students deficits" is composed by 7 items: items $2,5,18,22,32,34$, and 36 .
The scale of "School/teachers needs" is composed by 6 items: items 10, 25, 27, 29, 37, and 39.

The scale of "Learning/teaching process" is composed by 14 items: item 3, 6, 9, 11, 13, 14, 15, 17, 19, 21, 24, 26, 30 and 33.

Elevation in each one of the scales indicates that teachers perceive as having needs in the respective domain. Inversely, low scores on each scale means that teacher perceive as having little needs in the respective domain. There are not reversed items, meaning that all items measure in the same direction, with elevation indicating perception of higher needs.

\section{Results}

Principal components analysis, with the Promax rotation method, identified a four factors structure, with items loading on the expected factors. All the factors registered eigenvalues greater than two. Factor 1 (Socio-emotional needs related to teacher's initial training) explained 26,1\% of the variance, Factor 2 (Learning - teaching process socio-emotional needs) explained $12,5 \%$ of the variance, Factor 3 (Students' learning socio-emotional needs) explained $9,9 \%$ of the variance and Factor 4 (School/ teachers needs for socio-emotional skills promotion) explained $5,1 \%$ of the variance. The four factors accounted for $53,7 \%$ of the variance (with a Kaiser-Meyer-Olkin Measure of Sampling Adequacy [KMO]) value of .865 and an approximated Chi-Square, by Bartlett's Test of Sphecirity, of 6082,15 ( $d f=820 ; p=000)$.

Confirmatory factorial analysis was conducted to test the adjustment for the model. There was tested one model in which the independent variables were considered (model 1) and another model which considered the relation between variables (model 0 ). Model 0 revealed inadvisable adjustment values, given the $\chi^{2}$ fit $(740)=$ 2036.716, $p<.001, \chi^{2} / d f$ ratio $=2.752$, CFI $=.799$, RMSEA $=.081(90 \%$ confidence interval $=.077-.086)$. Model 1 provided a better fit to the data $\chi^{2}$ fit $(734)=$ $1930.295, p<.001, \chi^{2} / d f$ ratio $=2.630$, CFI $=.815$, RMSEA $=.078(90 \%$ confidence interval $=.074-.083)$, which attests its validity (Klein, 1998; Table 1).

Table 1

Results of the Confirmatory Factor Analysis of the TEPESSENI

\begin{tabular}{lccccc}
\hline Model & $\chi^{2}$ & $d f$ & $\chi^{2} / d f$ & CFI & RMSEA \\
\hline Model 1 independent & 2036.716 & 740 & 2.752 & .799 & $.081(.077-.086)$ \\
Model 2 correlated & 1930.295 & 734 & 2.630 & .815 & $.078(.074-.083)$ \\
\hline
\end{tabular}

\section{Reliability}

Total scale presented a total alpha value of .85. Alpha values from each subscale are good: Socio-emotional needs related to teacher's initial training $(\alpha=.954)$,
Students' learning socio-emotional needs $(\alpha=.79)$, School/teachers needs for socio-emotional skills promotion $(\alpha=.834)$, Learning - teaching process socio-emotional needs $(\alpha=.89)$. 
Moreira, P. A. S., Pinheiro, A., Gomes, P., Cotter, M. J. \& Ferreira, R. (2013). Development and Evaluation of Psychometric Properties of an Inventory of Teachers' Perceptions on Socio-Emotional Needs.

Table 2

Normalized Data for the Four Dimensions of the Teachers'Perceptions of Schooling Socio-Emotional Needs

\begin{tabular}{|c|c|c|c|c|}
\hline & \multicolumn{4}{|c|}{ One-Sample Statistics } \\
\hline & $n$ & Mean & $\begin{array}{c}\text { Std. } \\
\text { Deviation }\end{array}$ & $\begin{array}{l}\text { Std. } \\
\text { Error Mean }\end{array}$ \\
\hline Socio-emotional needs related to teachers' initial training & 266 & .3941 & 21638 & .01327 \\
\hline School and teachers needs for socio-emotional needs; & 263 & .5729 & .17500 & .01079 \\
\hline $\begin{array}{l}\text { Coping with students' socio-emotional effecting students } \\
\text { academic outcomes; }\end{array}$ & 265 & .5217 & .15470 & .00950 \\
\hline Learning / teaching process socio-emotional needs & 223 & .5397 & .16341 & .01094 \\
\hline
\end{tabular}

\section{Teachers' Perceptions of Socio-Emotional}

\section{Schooling Needs}

With the objective of understanding in which dimensions teachers feel more needs in terms of the promotion of social and emotional skills, the data was normalized. Results revel that teachers feel more needs in the school and teachers conditions for the promotion of social and emotional skills $(M=.57 ; S D=.17)$, followed by the promotion of social and emotional skills at the level of teaching/learning processes $(M=.54 ; S D=.16)$. The teachers' initial training was the dimension were teachers perceive to have less needs in terms of the promotion of social and emotional skills $(M=.39 ; S D=.21$; Table 2$)$.

\section{Teachers' Perceptions and Demographic Variables}

Male teachers registered more positive perceptions about Socio-emotional needs related to teacher's initial training, $(M=33.36, S D=9.9$ for male and $M=29.94$, $S D=9.5$ for female, $p=.015)$ but considered that they have more difficulties $(p=.022)$ in what concerns Learning teaching process socio-emotional needs $(M=48.39$, $S D=6.5)$ than female $(M=46.04, S D=7.0)$. Teacher's age was negatively correlated with Socio-emotional needs related to teacher's initial training $(r=-.180)$. No differences were found between teachers' perceptions and marital status, although individuals with no children $(M=$ $32.76, S D=9.28$ ) perceived their initial training regarding their preparation for social and emotional skills promotion more positively $(p=.018)$ than individuals with children $(M=29.75, S D=9.82)$.

\section{Teachers' Perceptions and Professional Variables}

Statistically significant differences were found in the scale of teachers' initial training perception $(p=.000)$, with first and second cycle individuals perceiving their initial training more positively (in what concerns addressing teaching socio-emotional needs) than secondary education teachers. No differences were found in terms of teachers' current professional situation. Teachers from different pedagogical groups presented statistically significant differences in Socio-emotional needs related to teacher's initial training $(p=.000)$ and in Learning - teaching process socio-emotional needs $(p=.011)$, but only between the pedagogical group of Humanities and social sciences and the group of gymnastics. Humanities and social sciences teachers perceived their initial training more negatively than gymnastics. Also, gymnastic teachers perceived having less difficulties in exercise of teaching than Humanities and social teachers. Years of service were found to be statistically significant negatively related to teachers' initial training perception regarding students' social and emotional needs $(r=-.174)$. Rural schools teachers presented a most positive $(M=32.65$; $S D=9.98)$ perception about their initial training than urban schools teachers $(M=29.64, S D=9.51 ; p=.016)$. Also among public schools a more positive teachers' initial training perception was found $(M=31.06 ; S D=9.7)$ when comparing to private schools teachers $(M=25.88$, $S D=8.3 ; p=.033)$. Teachers who graduated in private universities $(M=33.64 ; S D=8.5)$ perceived their teachers' initial training as more attentive to social and emotional needs of students than teachers that graduated in public universities $(M=29.94 ; S D=9.7 ; p=.012)$. Differences between groups regarding their initial training $(p=.044)$ were also found according to the academic degree. Teachers that attended additional training (for example, master degree or post graduation training; $M=29.09$; $S D=10.1$ ) perceived their initial training as having prepared them less for social and emotional skills promotion $(p=.039)$ than teachers without additional training $(M=$ $31.66 ; S D=9.3$ ).

\section{Discussion}

The goal of this study was to develop and to validate an instrument that could be used to identify and describe teacher's perceptions of their schooling socio-emotional needs. Confirmatory factorial analysis revealed indexes of acceptable adjustment and good values of internal consistency, both for the total scale score and for each one of the subscales.

Differences regarding the perception of difficulties faced by teachers were found in terms of gender, age, school level, school sector (private VS public), region 
(rural VS urban schools). These differences suggest that this instrument is sensitive to capture existing differences in teachers' perceptions, which are consistent with previous research. For example, the fact that rural teachers perceived themselves has having less teaching social and emotional needs than urban teachers may be understood by the fact that students from rural and urban schools present different tendencies of behaviors problems (S. L. Bender, Fedor, \& Carlson, 2011). Students from rural schools present more internalizing problems and students from urban schools tend to present more externalization problems (e.g., Hope \& Bieman, 1999). Urban school teachers tend to present higher levels of stress and burnout as a result of the demands and efforts that students' problematic behaviors represent (Abel \& Sewell, 1999), which may be understood to the dynamics between school and context characteristics and teachers individual characteristics (personality, perceptions) which result in several outcomes, such as teacher stress and burnout (CanoGarcia, Padilla-Munoz, \& Carrasco-Ortiz, 2005).

Teachers consider they have more needs at the school / teachers conditions for the promotion of socio-emotional skills, followed by difficulties in integrating the promotion of social and emotional skills in the daily teaching/learning process, followed by Difficulties in coping with students' socio-emotional affecting students academic outcomes. Teachers' initial training was the dimension teachers perceived as having less needs. These results confirm the importance of school characteristics for several academic outcomes (Cremers \& Kyriakides, 2006; K. Konstantopoulos, 2006). Indicators of teacher preparation and certification are between the stronger predictors of students' achievement in reading and mathematics, even when controlling student families' socio-economic status (DarlingHammond, 2000), and are associated to classroom quality and children's academic skills (Early et al., 2007) The fact that teachers perceived their initial training as the dimension they felt less difficulties should be explored by futures studies, namely studies evaluating teachers perceptions about their needs at the level of social and emotional skills promotion in teachers in their first years of work, in order to understand how their perception of their initial training may depend on their orientation for the present rather than the past (because present needs may become more relevant to teachers perceptions than past needs).

The behavior children exhibit in the classroom is impressionable based on the particular teachings they are receiving (Gose, 2006). Recent studies have shown that teachers' evaluations and perceptions have a significant role on teachers-students interactions and on teachers' behaviors for the promotion of students' adaptive biopsychosocial development (e.g. students' personality development; Heaven et al., 2009). The teacher support for learning is one dimension of recent multidimensional models of students' engagement with school which are receiving cross-cultural empirical validation (Moreira,
Vaz, Dias, \& Petracchi, 2009). Teachers have a significant effect on several indicators of academic trajectories (Nye, S. Konstantopoulos, \& Hedges, 2004), classrooms dynamics have a significant effect on students' achievement trajectories (Pianta, Belsky, Vandergrift, Houts, \& Morrison, 2008), and high and low expectations teachers impact on classroom interactions (Rubie-Davis, 2007). Addressing teachers' needs in the promotion of social and emotional skills has the potential of contributing to teachers' self-efficacy, which in turn have a significant impact on several indicators of teachers' biopsychosocial functioning, including on burnout (E. M. Skaalvik \& S. Skaalvik, 2007), and impact on teachers' efficacy (Tschannem-Moran \& Hoy, 2001).

This instrument may be usefully important for school improvement efforts by contributing to the changing process with the identification of teachers' needs in terms of the social and emotional determinants of learning and teaching and later development of strategies that may respond to those identified necessities. Examples of contributions of the use of this instrument include the understanding of the impact that the satisfaction of teachers' needs has (a) on students (e.g. teacher and students interactions, on students engagement with school, on students academic achievement, on students well-being, etc.) and, (b) on teachers (for example, on teachers burnout, or on teachers wellbeing). Also, it may relevant in evaluation of schoolbased health promotion interventions (including a better understanding about the moderating and/or mediating mechanisms of the teachers perceptions on the schoolbased social and emotional skills promotion programmes and strategies efficacy).

The interpretation of these results presents some limitations, which must be addressed by future studies. In order to assess convergent validity of this measure, future studies must assess the relation between this and other constructs. A larger sample would be desirable. Future studies should include larger samples, including teachers dealing with at risk samples, such as ethnic minorities or students with special educational needs. By other side, we suggest that the version tested in this study be improved, in terms of the instructions and in terms of items formulation. The proposed revised version in presented at the end of the article. Also, future studies should control schools characteristics which are associated to students socio-emotional functioning (students' socio-economic average level, students at risk for school dropout, etc.).

\section{References}

Abel, M. H., \& Sewell, J. (1999). Stress and burnout in rural and urban secondary school teachers. The Journal of Educational Research, 92, 287-293.

Archambault, I., Janosz, M., Morizot, J., \& Pagani, L. (2009). Adolescent behavioural, affective and cognitive engagement in school: Relationship to dropout. Journal of School Health, $79,408-415$. 
Moreira, P. A. S., Pinheiro, A., Gomes, P., Cotter, M. J. \& Ferreira, R. (2013). Development and Evaluation of Psychometric Properties of an Inventory of Teachers' Perceptions on Socio-Emotional Needs.

Battistich, V., Solomon, D., Kim, D., Watson, M., \& Schaps, E. (1995). Schools as communities, poverty levels of student populations, and students' attitudes, motives and performance: A multilevel analysis. American Educational Research Journal, 32, 627-658.

Bear, G. G., Manning, M. A., \& Izard, C. E. (2003). Responsible behavior: The importance of social cognition and emotion. School Psychology Quarterly, 18, 140-157.

Becker, B. E., \& Luthar, S. S. (2002). Social-emotional factors affecting achievement outcomes among disadvantaged students: Closing the achievement gap. Educational Psychologist, 37, 197-214.

Bender, S. L., Fedor, M. C., \& Carlson, J. S. (2011). Examining protective factors and risk factors in urban and rural head start Preschoolers. Journal of Community Psychology, 39, 908-921. doi: 10.1002/jcop.20477

Buckley, M., Storino, M., \& Saarni, C. (2003). Promoting emotional competence in children and adolescents: Implications for school psychologists. School Psychology Quarterly, 18, 177-191.

Cano-Garcia, F. J., Padilla-Munoz, E. M., \& Carrasco-Ortiz, M. A. (2005). Personality and contextual variables in teacher burnout. Personality and Individual Differences, 38, 929-940.

Carroll, J. B. (1963). A model of school learning. Teachers College Record, 64(8), 723.

Carroll, J. B. (1989). The Carroll Model: A 25-year retrospective and prospective view. Educational Researcher, 18, 26-31.

Coryn, C. L. S., Spybrook, J. K., Evergreen, S. D. H., \& Blinkiewicz, M. (2009). Development and evaluation of the Social-Emotional Learning Scale. Journal of Psychoeducational Assessment, 27, 283-295.

Cremers, B. P. M., \& Kyriakides, L. (2006). Critical analysis of the current approaches to modelling educational effectiveness: The importance of establishing a dynamic model. School Effectiveness and School Improvement: An International Journal of Research, Policy and Practice, 17(3), 347-366. doi: 10.1080/09243450600697242

Cruickshank, D. (1980). What are your teaching problems? In D. Cruickshank, J. Applegate, J. Holton, G. Mager, B. Myers, C. Novack, et al. (Eds.), Teaching is tough (pp. 31-44). Englewood Cliffs, NJ: Prentice-Hall.

Cruickshank, D. R. (1985). Applying research on teacher clarity. Journal of Teacher Education, 36(2), 244-248. doi: 10.1177/ 002248718503600210

Darling-Hammond, L. (2000). Teacher quality and student achievement: A review of state policy evidence. Education Policy Analysis Archives, 8.

Darling-Hammond, L., Holtzman, D. J., Gatlin, S. J., \& Heilig, J. V. (2005). Does teacher preparation matter? Evidence about teacher certification, teach for America, and teacher effectiveness. Education Policy Analysis Archives, 13.

Denham, S. A., Blair, K. A., DeMulder, E., Levitas, J., Sawyer, K., Auerbach-Major, S., et al. (2003). Preschool emotional competence: Pathway to social competence? Child Development, 74, 238-256.

Duckworth, A. L., \& Seligman, M. E. P. (2005). Self-discipline outdoes IQ in predicting academic performance of adolescents. Psychological Science, 16(12), 939-944. doi: 10.1111/ j.1467-9280.2005.01641.x

Durlak, J. A., Weissberg, R. P., Dymnicki, A. B., Taylor, R. D., \& Schellinger, K. B. (2011). The impact of enhancing student's social and emotional leaning: A meta-analysis of school-based universal interventions. Child Development, 82 , 405-432.
Early, D. M., Maxwell, K. L., Burchinal, M., Alva, S., Bender, R. H., Bryant, D., et al. (2007). Teachers' education, classroom quality, and young children's academic skills: Results from seven studies of preschool programs. Child Development, 78, 558-580.

Fine, S. E., Izard, C. E., Mostow, A. J., Trentacosta, C. J., \& Ackerman, B. P. (2003). First grade emotion knowledge as a predictor of fifth grade self-reported internalizing behaviors in children from economically-disadvantaged families. Development and Psychopathology, 15, 331-342.

Gose, S. H. (2006). Loving me or loving you: Influencing the attitudes and behaviors of children through a prosocial intervention. (Unpublished master's thesis). Graduate Faculty of the Louisiana State University and Agricultural and Mechanical College, Baton Rouge, LA.

Greenberg, M. T., Weissberg, R. P., O’Brian, M. U., Zins, J. E., Fredericks, L., Resnik, H., et al. (2003). Enhancing Schoolbased prevention and youth development trough coordinated social, emotional and academic learning. American Psychologist, 58, 466-474.

Guerra, N. G., Graham, S., \& Tolan, P. H. (2011). Raising healthy children: Translating child development research into practice. Child Development, 82, 7-16. doi:10.1111/j.1467.86242010.01537.x.

Heaven, P. C. L., Leeson, P., \& Ciarrochi, J. (2009). Personality development at school: Assessing a reciprocal influence model of teachers' evaluations and students' personality. Journal of Research in Personality, 43, 815-821.

Hope, T. L., \& Bieman, K. L. (1999). Patterns of home and school behavior problems in rural and urban settings. Journal of School Psychology, 36(1), 45-58.

Howse, R. B., Calkins, S. D., Anastopoulos, A. D., Keane, S. P., \& Shelton, T. L. (2003). Regulatory contributors to children's kindergarten achievement. Early Education and Development, 14, 101-119.

Huitt, W. (2003). A transactional model of the teaching/learning process. In Educational Psychology Interactive. Valdosta, GA: Valdosta State University.

Izard, C. E., Fine, S., Schultz, D., Mostow, A., Ackerman, B. P., \& Youngstrom, E. A. (2001). Emotion knowledge as a predictor of social behavior and academic competence in children at risk. Psychological Science, 12, 18-23.

Johnson, M. (1987). The body in the mind: The bodily basis of meaning, imagination, and reason. Chicago, IL: University of Chicago Press.

Kimber, B., Sandell, R., \& Bremberg, S. (2008). Social and emotional training in Swedish classrooms for the promotion of mental health: Results from an effectiveness study in Sweden. Health Promotion International, 23, 134-143.

Klein, L. R. (1998). Evaluating the potential of interactive media through a new lens. Journal of Business Research, 41, 195203

Klem, A. M., \& Connel, J. P. (2004). Relationship matter: Linking teacher support to student engagement and achievement. Journal of School Health, 74, 262-273.

Konstantopoulos, K. (2006). Trends of school effects on students achievement: Evidence from NLS: 72, HSB: 83, and NELS: 92. Teachers College Record, 108, 2250-2581.

Kurdek, L. A., \& Sinclair, R. J. (2000). Psychological, family, and peer predictors of academic outcomes in first-through fifth-grade children. Journal of Educational Psychology, 92(3), 449-457. doi: 10.1037/0022-0663.92.3.449 
Lam, B., \& Kember, D. (2006). The relationship between conceptions of teaching and approaches to teaching. Teachers and Teaching: Theory and Practice, 12(6), 693-713. doi: 0.1080/13540600601029744

Lane, K. L, Givner, C. C., \& Pierson, M. R. (2004). Teacher expectations of student behaviour: Social skills necessary for success in elementary school classrooms. The Journal of Special Education, 38, 104-110.

Lundervold, A. J., Posserud, M.-B., Ullebo, A. M., Sorensen, L., \& Gillberg, C. (2011). Teachers reports of hypoactivity symptoms reflect cognitive processing speed in primary school children. European Journal of Child and Adolescent Psychiatry, 20, 121-126.

Maandag, D. W., Deinum, J. F., Hofman, W. A., \& Buitink, J. (2007). Teacher education in schools: An international comparison. European Journal of Teacher Education, 30, 151-173.

Martin, B. (2007). Social and emotional learning in schools: A glimpse into the future? Primary \& Middle Years Educator, 5, 22-27.

Merrel, K. W. (2002). Social-Emotional intervention in schools: Current status, progress and promise. School Psychology Review, 31, 143-147.

Moreira, P., Crusellas, L., Sá, I., Petracchi, P., \& Matias, C. (2010). Evaluation of a manual-based programme for the promotion of social and emotional skills in elementary school children: Results from a 4 year study in Portugal. Health Promotion International, 25, 309-317.

Moreira, P., Vaz, F. M., Dias, P., \& Petracchi, P. (2009). Psychometric properties of the Portuguese version of the School Engagement Instrument. Canadian Journal of School Psychology, 24(4), 303-317.

Preto, M. \& Moreira, P.A.S. (2012). Auto-regulação da aprendizagem em crianças e adolescentes vítimas de violência doméstica contra mulheres [Learning self-regulation in children and adolescents of women victims of domesctic violence/ intimate partner violence]. Psicologia: Reflexão e Crítica, 5(4), 730-737

Mostow, A. J., Izard, C. E., Fine, S., \& Trentacosta, C. J. (2002). Modeling emotional, cognitive and behavioural predictors of peer acceptance. Child Development, 73, 1775-1787.

Nye, B., Konstantopoulos, S., \& Hedges, L. V. (2004). How large are teacher effects? Educational Evaluation and Policy, 43, 971-990.

Pavarini, G., Loureiro, C. P., \& Souza, D. H. (2011). Compreensão de emoções, aceitação social e avaliação de atributos comportamentais em crianças escolares. Psicologia: Reflexão e Crítica, 24(1), 135-146.

Pavri, S., \& Hegwer-DiVita, M. (2006). Meeting the social and emotional needs of students with disabilities: The special educators' perspective. Reading \& Writing Quarterly: Overcoming Learning Difficulties, 22(2), 139-153. doi: 10.1080/ 10573560500242200

Payton, J. D., Wadlaw, D. M., Graczyk, P. A., Bloodworth, M. R., Tompsett, C. J., \& Weissberg, R. P. (2000). Social and emotional learning: A framework for promoting mental health and reducing risk behaviors in children and youth. Journal of School Health, 70, 179-185.

Pedder, D., \& MacBeath, J. (2008). Organisational learning approaches to school leadership and management: Teachers' values and perceptions of practice. School Effectiveness and School Improvement: An International Journal of Research, Policy and Practice, 19(2), 207-224. doi: 10.1080/ 09243450802047899
Pianta, R., Belsky, J., Vandergrift, N., Houts, R. M., \& Morrison, F. J. (2008). Classroom effects on children's achievement trajectories in elementary school. American Educational Research Journal, 45, 365-397.

Poulou, M. (2006). Educational psychology within teacher education. Teachers and Teaching: Theory and Practice, 11, 555-574

Pritchard, M. E., \& Wilson, G. S. (2003). Using emotional and social factors to predict student success. Journal of College Student Development, 44, 18-28.

Reschly, A. M., Huebner, E. S., Appleton, J. J., \& Antaramian, S. (2008). Engagement as flourishing: The contribution of positive emotions and coping to adolescents' engagement at school and with learning. Psychology in Schools, 45, 419-431.

Rivkin, S. G., Hanushek, E. A., \& Kain, J. F. (2005), Teachers, schools, and academic achievement. Econometrica, 73, 417458. doi: 10.1111/j.1468-0262.2005.00584.x

Rosenblatt, J., \& Elias, M. J. (2008). Dosage effects of a preventive social-emotional learning intervention on achievement loss associated with middle school transition. Journal of Primary Prevention, 29, 535-555.

Rubie-Davis, C. M. (2007). Classroom interactions: Exploring the practices of high and low expectation teachers. British Journal of Educational Psychology, 77, 289-306.

Slavin, R. (1995). A model of effective instruction. The Educational Forum, 59, 166-176.

Skaalvik, E. M., \& Skaalvik, S. (2007). Dimensions of teacher self-efficacy and relations with strain factors, perceived collective teacher efficacy, and teacher burnout. Journal of Educational Psychology, 99, 611-625. doi: 10.1037/00220663.99.3.611

Stanulis, R., Fallona, C., \& Pearson, C. (2002). 'Am I doing what $i$ am supposed to be doing?': Mentoring novice teachers through the uncertainties and challenges of their first year of teaching. Mentoring \& Tutoring: Partnership in Learning, 10, 71-81.

Stronge, J. H. (2007). Qualities of effective teachers ( $2^{\text {nd }}$ ed.). Alexandria, VA: Association of Supervision and Curriculum Development.

Tetler, S., \& Baltzer, K. (2011). The climate of inclusive classrooms: The pupil perspective. London Review of Education, 9, 333-344.

Tschannem-Moran, M., \& Hoy, A. W. (2001). Teacher efficacy: Capturing an elusive construct. Teaching and Teacher Education, 17, 783-805.

Weiner, B. (1995). Judgments of responsibility: A foundation for a theory of social conduct. New York: Guilford Press.

Welsh, M., Parke, R. D., Widamen, K., \& O’Neil, R. (2001). Linkages between children's social and academic competence: A longitudinal analysis. Journal of School Psychology, 39, 463-482. 
Moreira, P. A. S., Pinheiro, A., Gomes, P., Cotter, M. J. \& Ferreira, R. (2013). Development and Evaluation of Psychometric Properties of an Inventory of Teachers' Perceptions on Socio-Emotional Needs.

\section{Appendix A}

Teachers' Perceptions of Schooling Socio-Emotional Needs Inventory - Revised Version (TEPESSENI-R) (Paulo Moreira, Lusíada University, Porto, Portugal)

$\begin{array}{cccr}\text { Totally } & \text { Disagree } & \begin{array}{c}\text { No agree } \\ \text { nor } \\ \text { disagree }\end{array} & \text { disagree }\end{array} \quad \begin{array}{r}\text { Agree } \\ \text { Totally } \\ \text { agree }\end{array}$

1. My initial training prepared me to promote students' social skills

2. I have difficulties in coping with students' deficits on self-esteem and on self-confidence

3. In my daily teaching practice, I have difficulties in coping with students' disruptive behaviors in the classroom

4. My initial training prepared me to deal with students' disruptive behaviors in the classroom

5. I have difficulties in coping with students' deficits on decision making

6. In my daily teaching practice, I have difficulties in coping with students' victims of maltreatment

7. My initial training prepared me to understand students' behaviors

8. My initial training prepared me to promote the curricular and programmatic contents

9. In my daily teaching practice, I have difficulties in understanding students' behaviors

10. Specialized materials to help teachers intervening on school failure are insufficient in this school

11. In my daily teaching practice, I have difficulties in promoting sexual education

12. My initial training prepared me to promote students' self-esteem and self-confidence

13. In my daily teaching practice, I have difficulties in promoting decision making strategies

14. In my daily teaching practice, I have difficulties in promoting students self-control and self-regulation

15. In my daily teaching practice, I have difficulties in promoting students' social skills

16. My initial training prepared me to promote students' sexual education

17. In my daily teaching practice, I have difficulties in promoting students' self-esteem and self-confidence

18. I have difficulties in coping with students' deficits on self-control and on self-regulation

19. In my daily teaching practice, I have difficulties in promoting students' vocational knowledge and development

20. My initial training prepared me to promote students' emotion regulation

21. In my daily teaching practice, I have difficulties in motivating students' for learning

22. I have difficulties in coping with students' maltreatment

23. My initial training prepared me to identify students' emotional states

24. In my daily teaching practice, I have difficulties in maintaining discipline in the classroom

\begin{tabular}{|c|c|c|c|}
\hline 1 & 2 & 3 & 4 \\
\hline 1 & 2 & 3 & 4 \\
\hline 1 & 2 & 3 & 4 \\
\hline 1 & 2 & 3 & 4 \\
\hline 1 & 2 & 3 & 4 \\
\hline 1 & 2 & 3 & 4 \\
\hline 1 & 2 & 3 & 4 \\
\hline 1 & 2 & 3 & 4 \\
\hline 1 & 2 & 3 & 4 \\
\hline 1 & 2 & 3 & 4 \\
\hline 1 & 2 & 3 & 4 \\
\hline 1 & 2 & 3 & 4 \\
\hline 1 & 2 & 3 & 4 \\
\hline 1 & 2 & 3 & 4 \\
\hline 1 & 2 & 3 & 4 \\
\hline 1 & 2 & 3 & 4 \\
\hline 1 & 2 & 3 & 4 \\
\hline 1 & 2 & 3 & 4 \\
\hline 1 & 2 & 3 & 4 \\
\hline 1 & 2 & 3 & 4 \\
\hline 1 & 2 & 3 & 4 \\
\hline 1 & 2 & 3 & 4 \\
\hline 1 & 2 & 3 & 4 \\
\hline 1 & 2 & 3 & 4 \\
\hline
\end{tabular}




\begin{tabular}{|c|c|c|c|c|c|}
\hline & $\begin{array}{c}\text { Totally } \\
\text { disagree }\end{array}$ & Disagree & $\begin{array}{c}\text { No agree } \\
\text { nor } \\
\text { disagree }\end{array}$ & Agree & $\begin{array}{r}\text { Totally } \\
\text { agree }\end{array}$ \\
\hline $\begin{array}{l}\text { 25. Support services to help teachers dealing with students } \\
\text { academic difficulties are insufficient in this school }\end{array}$ & 1 & 2 & 3 & 4 & 5 \\
\hline 26. In my daily teaching practice, I have difficulties & & & & & \\
\hline in identifying students' emotional states & 1 & 2 & 3 & 4 & 5 \\
\hline $\begin{array}{l}\text { 27. Teachers from this school have difficulties in addressing } \\
\text { the students' specific characteristics and needs }\end{array}$ & 1 & 2 & 3 & 4 & 5 \\
\hline $\begin{array}{l}\text { 28. My initial training prepared me to deal with students' risk } \\
\text { behaviors (e.g. drug consumption, etc.) }\end{array}$ & 1 & 2 & 3 & 4 & 5 \\
\hline $\begin{array}{l}\text { 29. Teachers from this school have difficulties in articulation } \\
\text { students' socio-emotional needs with the } \\
\text { curricular/programmatic contents }\end{array}$ & 1 & 2 & 3 & 4 & 5 \\
\hline $\begin{array}{l}\text { 30. In my daily teaching practice, I have difficulties } \\
\text { in promoting students' emotion self-regulation }\end{array}$ & 1 & 2 & 3 & 4 & 5 \\
\hline $\begin{array}{l}\text { 31. My initial training prepared me to motivate students } \\
\text { for learning }\end{array}$ & 1 & 2 & 3 & 4 & 5 \\
\hline $\begin{array}{l}\text { 32. I have difficulties in coping with students' deficits } \\
\text { on social skills }\end{array}$ & 1 & 2 & 3 & 4 & 5 \\
\hline $\begin{array}{l}\text { 33. In my daily teaching practice, I have difficulties in coping } \\
\text { with students' risk behaviors (e.g. drug consumption) }\end{array}$ & 1 & 2 & 3 & 4 & 5 \\
\hline $\begin{array}{l}\text { 34. I have difficulties in coping with students' deficits } \\
\text { on emotion identification and regulation }\end{array}$ & 1 & 2 & 3 & 4 & 5 \\
\hline $\begin{array}{l}\text { 35. My initial training prepared me to promote students' } \\
\text { self-control and self-regulation }\end{array}$ & 1 & 2 & 3 & 4 & 5 \\
\hline $\begin{array}{l}\text { 36. I have difficulties in coping with students' lack } \\
\text { of motivation to learning }\end{array}$ & 1 & 2 & 3 & 4 & 5 \\
\hline $\begin{array}{l}\text { 37. The school has difficulties in addressing the students' } \\
\text { specific characteristics and needs }\end{array}$ & 1 & 2 & 3 & 4 & 5 \\
\hline $\begin{array}{l}\text { 38. My initial training prepared me to identify and } \\
\text { to deal with students victims of maltreatment }\end{array}$ & 1 & 2 & 3 & 4 & 5 \\
\hline $\begin{array}{l}\text { 39. Teachers from this emphasize mostly curricular/programmatic } \\
\text { issues, compared to socio-emotional dimensions }\end{array}$ & 1 & 2 & 3 & 4 & 5 \\
\hline
\end{tabular}

\section{Coding instructions}

The scale of "Initial training" is composed by 12 items: items 1, 4, 7, 8, 12, 16, 20, 23, 28, 31, 35 and 38 . The scale of "Coping with Students deficits" is composed by 7 items: items 2, 5, 18, 22, 32, 34, and 36.

The scale of "School/teachers needs" is composed by 6 items: items 10, 25, 27, 29, 37, and 39.

The scale of "Learning/teaching process" is composed by 14 items: item 3, 6, 9, 11, 13, 14, 15, 17, 19, 21, 24, 26,30 and 33 .

Elevation in each one of the scales indicates that teachers perceive as having needs in the respective domain. Inversely, low scores on each scale means that teacher perceive as having little needs in the respective domain. There are not reversed items, meaning that all items measure in the same direction, with elevation indicating perception of higher needs. 